\title{
Urban transportation system design and feasibility analysis A case study of Lagos Mega-City
}

\author{
SOWOPUTI Adetose Emmanuel ${ }^{* 1}$, SALAAM O. Taiwo ${ }^{2}$ \\ ${ }^{1}$ Department of Transport Management Technology, School of Management Technology, Federal University of \\ Technology Akure, Nigeria. \\ esoteda@yahoo.com
}

${ }^{2}$ Lagos State Ministry of Transport, Lagos, Nigeria.

salaamtaiwo@yahoo.com

\begin{abstract}
This paper examines how urban transportation, urban mobility and urban land Planning at urban Centres influence urban space that serves a variety of human needs; housing, working, social interaction, leisure, and mobility of persons and goods. Transportation and planning are co-dependent, mutually influencing each other in complex and dynamic ways. To create a livable urban environment, there is a need to balance transportation with planning. The skewers of any of these will result in serious environment issues. To identify the role and impact of road transportation in a mega city, the research methodology adopted in this work utilized environmental management system techniques. Key impacts on local community includes exchange of energy, function and maintenance of ordered structures, directly or indirectly supplied and maintained by natural system. Various socio-economic activities and professional judgment from the findings shows that spatial distribution of housing, working, shopping, leisure and other activities determines average trip distances in urban mobility. High population density as well as a mixture of land use for various social and economic activities, maintains low distances between origin and destination of urban trips. It also shows that road development parameters were well within the range of metropolis city, the low density urban development and large road areas increases trip length and lead to higher share of automobile trips. The study recommends that the state government should engaged in traffic management by adjusting the use of existing road system to improve traffic operation without resorting to major new constructions, provision of time-based traffic lights, and enforcement of traffic lights and signs, manning of road junctions by traffic wardens, constructing overhead bridges and zebra crossings, encouragement of park and ride system and educating drivers and ensure compulsory written test before the issuance of any driving license. This can be embarked through a technology- supported joint venture that aims to integrate and systematically optimize the State's intermodal transportation system.
\end{abstract}

Keywords: Urban Transportation, Urban Mobility, Urban land Use Planning

\section{Introduction}

Urban transportation system design and feasibility analysis examines the relationship that exist between land use planning and urban mobility in urban centers, where urban space serves a variety of human needs; housing, working, social interaction, Leisure and mobility of persons and goods. To create a livable urban environment, there is need to balance transportation with planning. Transportation is a necessary pre-requisite for development. However, this relationship works in both directions. Land use patterns and built environments share the demand for travel (Jayasinghe, Sano, \& Rattanaporn, 2017).
Mobility especially in the form of motorized transport, requires an increasing share of land both within cities and in rural areas. Cities in highly motorized countries dedicate much of their urban area for roads. High population density as well as a mixture of land users for various social and economic activities maintain little distances urban development while large road areas increases trip length and lead to a higher share of automobile trips. Town planners can contribute to minimize trip length in urban areas by taking these into cognizance. (Badejo, 1986). International comparative studies have shown that there are close links between population density,

*Corresponding Author:

Email address: esoteda@yahoo.com

DOI: http://doi.org/10.4038/bhumi.v6i2.45 
motor vehicle use and per capital energy consumptions in transport sectors.

Transportation in urban areas is highly complex because of the modes involved, the multitude of origins and destinations, and the amount and variety of traffic. Urban transportation has been on passengers as cities were viewed as locations of utmost human interactions with intricate traffic patterns linked to commuting, commercial transactions and leisure / cultural activities. Urbanization has been one of the dominant contemporary processes as a growing share of the global population lives in cities. Considering this trend, urban transportation issues are of foremost importance to support the passengers and freight mobility requirements of large urban.( Jean -Paul Rodrigue, 2013).

The historical evolution of urban centers in Nigeria indicates the dominating role of transport development, the construction of dense network of roads and the introduction of the automobile gradually changed the face of these cities. Over the time, it led to the development of complex transport system which enhance the movement of people and goods from one point of the city to another. The unending long queues at bus-stops, the stand still vehicles; on urban roads, the absence of parking lots, the high rate of urban- traffic accidents, environmental pollution and noise among others present; a clear testimony to this negative role of transport in urban centers and call for attention. Until the evolution of the Federal Urban Mass Transit Program me in 1988, the urban transport was one of the most neglected sub-sectors of the national transport system development. "The metropolitan cities have grown to the point where they threaten to strangle" (Owoputi, 2015). With the technical problems, data and methodological constraints in developing counties (Jayasinghe, Sano, \& Nishiuchi, 2015) well in hand the modern cities are faced with traffic problems more complex than ever before. "Despite all the methods of movement, the problems in cities is how to move" (Owen, 1956).

Human movement is fundamental in the creation, development and growth of settlements. Associated with the rising population and rapidly expanding cities are various urban problems, such as unemployment, and housing problems. Environmental, population, mobility problems and general inadequacy of infrastructural facilities. The increased urban population, the expansion of road longer urban journeys and increased urban trip volumes have all placed a great burden on land use, urban planning and on city's transport system, which becomes an urban mobility problems (Owoputi, 2016)). The situation is not new, In ancient Rome, wheeled Chariots had to be banned from being used along some roads during the day. Modern automobile created serious congestion problem in England in 1962, that the government commissioned a study to be conducted by a team led by Engineer Buchanan. ( Trimbath, 2011 ) ; Unfortunately there are no universal solutions, as the problems - vary from one environment to another.

\subsection{Urbanization and the Evolution of Transport Problems in Nigeria Cities}

Urbanization, urban expansion and transportation are intricately interwoven. The rate and the pattern of growth have not been uniform all over the world. Nigeria is one of the countries in the developing world with rapid urbanization and fast growing cities, Particularly Lagos Mega City. ( Mabogunje, 1968). The morphology of Lagos City was essentially concentric. The center of the city harbored the heads palace and was the center of educational institutions, commercials, administrative and recreational and social activities. Since no mechanical transport, the need for long distance movement was reduced through rather compact multipurpose building erected around the center.

The key Characteristics of Lagos City Urban Transport Problem are :- high incidences of inadequate attention to provision for movement needs in planned and unplanned settlements, inadequate awareness of transport implications of land use developments, increasing journey distance and travel time, often due to transport system deficiencies, absence of long term strategic perspectives in transport actions resulting in reactive rather than prescriptive planning, application of urban and road design standards often without social cultural and economic realities in terms of land use planning, the neglect of non-motorized mode of travel, inadequate institutional frame works for land use plan and city mobility formulation plan and implementation of different users of urban land plan and transportation, in effectiveness of traffic and land use control and regulatory instruments.

Lagos state mega city currently maintains a vast transportation network used for mobility of passengers, goods and services around the state. As the current infrastructure of the Lagos mega city intermodal transportation system approaches its capacity. Congestion ensues resulting in lost time and revenues. Alternative means for augmenting transport capacity in urban city are thus explored. Determining the economic viability and feasibility of integrating urban transportation and urban land use planning into the Lagos mega city urban, mobility 
system is an issue currently faced by Lagos Metropolitan Area Transport Authority [ LAMATA].

The challenge of urban transportation in Lagos State has been summarized by LAMATA that "The transport system is inadequate for the growing urban population in the mega city. All modes of transport have challenges, the bus-based public transport operations suffers from high levels of fragmentation and inadequate regulations (LAMATA, 2015). The rail transport has a few existing rail corridors and those corridors are grossly under- utilized. In the water transport, there is no coherence among water transport regulation agencies such as Lagos State Water Authority, (LASWA), National Maritime Administration and Safety Agency (NIMASA) and Nigeria Inland Waterway Authority (NIWA). The non-motorized transport infrastructure facilities are extremely limited throughout the mega city. In the para-transit mode of transportation, motor cycle known as 'Okadas' riders are undisciplined and regulations neither effectively enforced nor fully integrated with the intermodal system making the great potential for low-cost transport is underutilized. Unfortunately, there are several factors impeding the integration of the intermodal systems with existing river facilities, such as the river, jetties which is in a serious state of disrepair and would require extensive funding to upgrade and maintain.

\subsection{Urban Mobility, Urban Land Use Planning}

Contributions on the theoretical and conceptual issues in urban transport from many researchers have observed the central role of transportation in emerging cities like Lagos. Ayeni ( Ayeni, 1975 ) has constructed a model after Lowry and utilized the model to forecast the future pattern of journey to work by various categories of income groups. In 1983, his research on the development of urban land use-based transportation model for Lagos attempted to replicate his previous study (Ayeni, 1975 ) of Jos in Lagos. He provided a synthesis of the social characteristics of the urban residents and showed how these can be woven into the rudiment of urban land use-based transportation system modeling. In another land usetransport related study Ayeni has identified some determinants of the propensity to interact and showed how these can be used for estimating the volume of movement in the city. Banjo (Banjo 1984, 1986 \& 1989) proposed a framework for examining the performance level of urban mass transit system in the city. Ogunsanya (Ogunsanya, 1986) suggested the use of graph theory to explain intra- urban networks.

Urban transportation is organized in three board categories of collective, individual and freight. The purpose of collective transportation is to provide publicly accessible mobility over specific parts of a city. These systems are typically owned and operated by an agency and access is opened to all as long as a fare is paid; therefore, it is called public transit. It is utilized for large-scale transporting of people and achieving economies of scale with buses, trains and ferry boats. Individual transportation includes any mode where mobility is the outcome of a personal choice and means such as the automobile, walking, cycling and the motorcycle. As cities are dominant centers of production and consumption, urban activities are accompanied by large movements of freight. These distribution centers, are mostly characterized by delivery trucks moving between industries, distribution centers, warehouses and retail activities as well as from major terminals such as ports, rail yards, distribution centers and airports.

Land use planning is the general term used for a branch of urban planning encompassing various disciplines which seeks to order and regulate land use in an efficient and ethical way, thus preventing land use conflicts. Governments employ land use planning to manage the development of land within their jurisdictions. City planners shall aware of which areas of a city are used for which purpose. Therefore, they produce a map of "land use" that identifies parts of a city and the major activities that happen there.

Urbanization has been described as the population shift from rural to urban areas, the ways in which the society adapts to the change, it is essentially a settlement process in which a new set of settlement patterns emerge as a result of shifts in sectorial economy. (Oyesiku, 1997) identified 3 factors responsible for urbanization which are natural increase (excess of birth over deaths ), rural to urban migration, and city expansion into surrounding rural areas.

\section{Methods and Materials}

\subsection{Lagos as the case study}

To identify the role and impact of road transportation in African mega cities, the research method adopted a field study in Lagos City in the south western part of Nigeria which is regarded as the most urbanized section in Africa. Lagos as the largest city in Nigeria is located at Latitude $626^{\prime}$ North of the equator and longitude 3 38' East of the Greenwich meridian. It was formerly the capital of Nigeria and is now regarded as a mega city with a population of more than 16 million people and a projected population of about 20 million people by the year 2020. Lagos as a city state has a total land area of $3,577,23$ sq. kilometers representing about $22 \%$ of wetland having a population density of 
6,575 person per sq. kilometers (Lagos State government 2013).

The population density and urbanization of Lagos mega city is currently stands as one of the largest urban areas in the world and is on the verge of becoming a primary coastal megalopolis. Lagos mega city area is home to approximately $33 \%$ of the Lagos population ( Sunday \& Ajewole, 2006 ).

Lagos population is growing rapidly at a rate of nearly $3.2 \%$ per annum. The poor condition of the road networks and of the public transport system affects the development of the city in several ways, particularly, working and living conditions of the population are the most vulnerable.

Rapid growth of the private vehicle fleet, combined with reliance on commercial vehicles and motorcycles. Coastal buses known as 'Danfo', Shared Taxis (i.e., Colourful cars in Lagos), Motorcycles and Tri -cycle known as 'Keke-Maruwa' and boats have resulted poor quality public transport infrastructure and an extreme traffic congestion across Lagos city. Public transport in Lagos city could largely be described as unregulated, chaotic, in-efficient, expensive, low-grade quality and dangerous in terms of road traffic accidents and personal safety. There are about $2600 \mathrm{~km}$ of roads in Lagos that are frequently congested, with over one million vehicles along the roads on a daily basis.

With the rising population and population density, over $70 \%$ Lagosians live in slum areas without any strong basis for land use planning and sustainable transformation of the city.

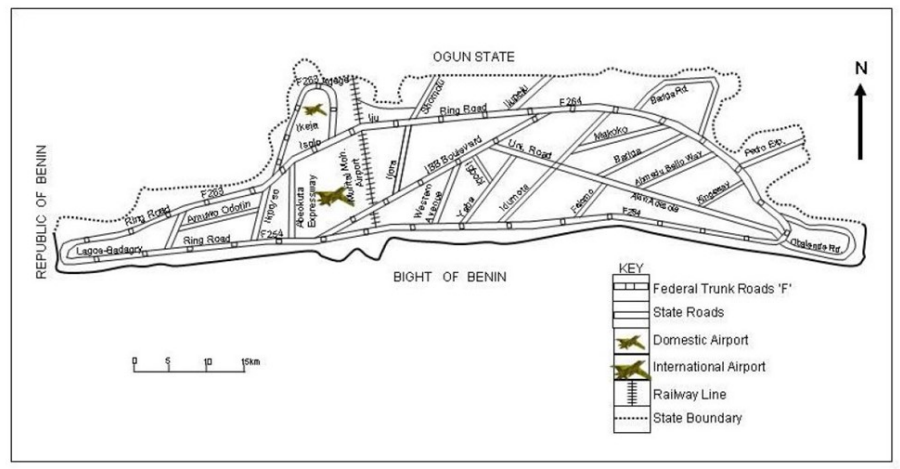

Figure 1: Map of Lagos State showing road transport network

Source:- Federal Ministry of works and housing (2004) updated by fieldwork (2015).

\subsection{Method of study}

Site investigations, visitations and analysis were conducted coupled with interviews of professionals in relevant fields. Interviews with intended users were designed to probe into pressing issues like functions, objectives, activities, facilities and implementation of transportation. The intended users were architects, mode users, operators, traffic officers, city planners, land use managers. The computed direct physical distance was utilised to analyze the spatial mobility of locations in relation to the point of distribution of their activity pattern. Simple ratios and percentages were used to explain the observed distribution in addition to the computed correlation coefficients between distance and traffic congestion, land use and the distance travel to patronize urban activity modes.

\section{Results and discussion}

The migration of teeming population into 3rd world cities do not have complementary technical facilities to make these urban centers places of comfort but conglomeration of problems in the mega city. Lagos mega city is not spared from these problems. The mega city mostly consists of the business space along with some residential areas (Fig. 2). The price and the rent of space is usually very high due to the limited space availability and the high demand regardless the transportation network is poorly developed. These areas usually have land- use planning problems with a spiral downwards unless revived with compressive road network transportation redevelopment schemes.

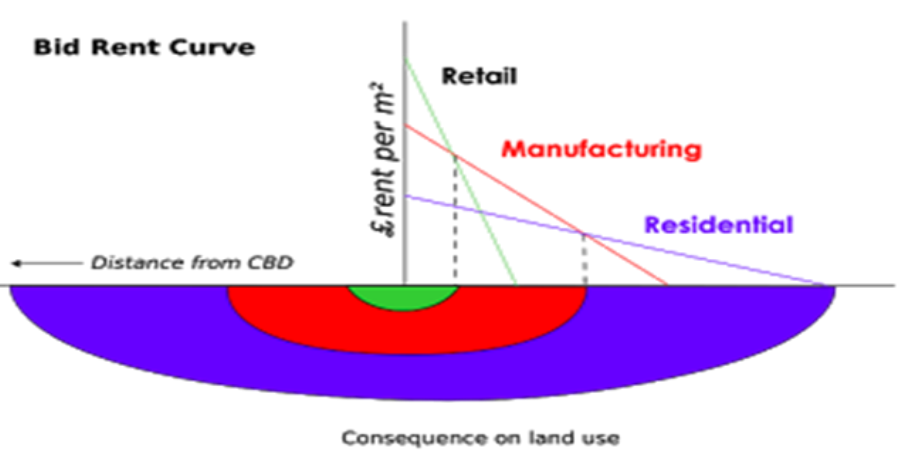

Figure 2: Neo Plano Space, Internal structure of cities (Source: Brian J. L. Berry, MINGGU 2011, Wikipedia)

Immediately outside the city lie midrises predominantly residential nature which is usually well linked to the city centre through public transport. The current status of transportation in Lagos City shows that the transportation networks in the state is predominantly road-based with $90 \%$ of total passengers and goods move through this mode. The city has natural waterways for ferry services and federal rail networks which would be complimented by the emerging state city rail networks. The trip demands in Lagos mega city region by all modes in walking was estimated at 22 million per day with work trips accounting for $40 \%$ of total trips in metropolitan Lagos city. The rapid increases in population and improvement in standard at living will bring the Table 1: Passenger Traffic per Day in Lagos city 


\begin{tabular}{|c|c|c|c|}
\hline NO & Mode & Passenger per day & $\begin{array}{l}\text { Percent- } \\
\text { age }\end{array}$ \\
\hline 1 & Walking & $8,800,000$ & 40 \\
\hline 2 & BRT (Bus Rapid Transit) & 90,000 & 0.17 \\
\hline 3 & LAGBUS (i.e., a metropolitan bus service in Lagos) & 150,000 & 1.10 \\
\hline 4 & Private cars & $2,508,000$ & 11 \\
\hline 5 & Semi formal mini buses 'Danfo' & $9,982,000$ & 45 \\
\hline 6 & Federal mass transit train & 132,000 & 10 \\
\hline 7 & Water transportation system & 74,000 & 0.13 \\
\hline 8 & $\begin{array}{l}\text { Other modes (motorcycle, tricycle, bicycle, taxis, Articulated vehicles, mini } \\
\text { vans, boats) }\end{array}$ & 264,000 & 1.60 \\
\hline $\mathrm{T}$ & Total passenger traffic / Daily 100 & $22,000,000$ & 100 \\
\hline
\end{tabular}

Source : LAMATA 2015.

daily demand for trips to about 40 million per day by 2032 ( LAMATA 2014 ).

Table 2: Population Projections for Lagos Mega City between $2015-2050$

\begin{tabular}{|l|r|r|r|}
\hline No & year & $\begin{array}{r}\text { Population density/ } \\
\text { km }\end{array}$ & $\begin{array}{c}\text { Population } \\
\text { Density / km }\end{array}$ \\
\hline 1 & 2015 & $23,305,971$ & 6,515 \\
\hline 2 & 2020 & $27,281,339$ & 7,626 \\
\hline 3 & 2025 & $31,934,798$ & 8,927 \\
\hline 4 & 2030 & $37,382,011$ & 10,450 \\
\hline 5 & 2032 & $39,812,738$ & 11,450 \\
\hline 6 & 2035 & $43,758,371$ & 12,232 \\
\hline 7 & 2040 & $51,222,365$ & 14,319 \\
\hline 8 & 2045 & $59,959,516$ & 16,761 \\
\hline 9 & 2050 & $70,186,998$ & 19,620 \\
\hline
\end{tabular}

Source: Urban mobility research group, Her rich Boll Stiffing, 2015

Inadequately designed interchanges provide only partial access to the primary network. Many tertiary roads play the role of secondary ones, so far few junctions have been signalized whereas the limited available transport stations are also at a disorganized state (Owoputi, 2016). This emphasizes the degree of inadequacy in the transport infrastructure and land use planning in the state.

With the formal public transportation contributing only $2.75 \%$ of daily mobility in the city, it is clear that these modes cannot meet the demand of the Lagos residents. Hence semi-formal and informal operations from mini buses (Danfo ), motorcycles, tricycles and boats (specially popular among Makoko Community) are being continued to fill the gap. Underlying need to fill the gap by operations have to addressed the unemployment and high poverty rate in the city and not necessarily as a choice career or transportation sector by unemployed youth and other categories of the population who seek means of livelihood has contributed to traffic chaos and unethical behaviors among the informal operators.

Table 3: Level of Road Infrastructure in Lagos City

\begin{tabular}{|l|l|r|r|}
\hline No & \multicolumn{1}{|c|}{ Classification } & $\begin{array}{c}\text { Length } \\
(\mathbf{k m})\end{array}$ & \multicolumn{1}{|c|}{ Percentage } \\
\hline 1 & Federal road & 468 & $6 \%$ \\
\hline 2 & State road & 1,287 & $17 \%$ \\
\hline 3 & Local govern. Road & 5843 & $77 \%$ \\
\hline 4 & Total road network & 7,598 & $100 \%$ \\
\hline
\end{tabular}

Source: Lagos Metropolitan Area Transport Authority, 2015

Table 4: Details of transport modes in Lagos city

\begin{tabular}{|c|l|l|}
\hline $\mathbf{N}$ & \multicolumn{1}{|c|}{ Item } & \multicolumn{1}{c|}{ Number } \\
\hline 1 & $\begin{array}{l}\text { Total of vehicles on the } \\
\text { road }\end{array}$ & $\begin{array}{l}\text { Approximatrly about } \\
2,000,000\end{array}$ \\
\hline 2 & $\begin{array}{l}\text { Annual rate of increase } \\
\text { of vehicles }\end{array}$ & $\begin{array}{l}100,000 \text { vehicles per an- } \\
\text { num }\end{array}$ \\
\hline 3 & Vehicular Density & $\begin{array}{l}264 \text { vehicles per km of } \\
\text { roadway }\end{array}$ \\
\hline 4 & High capacity Buses & $\begin{array}{l}\text { Approx. 1,034 (BRT old), } \\
100 \text { (BRT - new), 434 LAG- } \\
\text { BUS }\end{array}$ \\
\hline 5 & Mini Buses (Danfo) & Over 145,000 (registered) \\
\hline 6 & $\begin{array}{l}\text { High capacity Buses } \\
\text { (Molue) }\end{array}$ & $\begin{array}{l}\text { Less than 150 being } \\
\text { phased out }\end{array}$ \\
\hline 7 & Taxis & $\begin{array}{l}\text { Estimated at around } \\
7,000\end{array}$ \\
\hline 8 & Other vehicles & $\begin{array}{l}\text { Estimated at around } \\
5,000\end{array}$ \\
\hline 9 & Motor cycles & $\begin{array}{l}\text { Estimated around } \\
100,000\end{array}$ \\
\hline
\end{tabular}

Source : Lagos Metropolitan Area transport Authority, 2015

With the formal public transportation contributing only $2.75 \%$ of daily mobility in the city, it is clear that these modes cannot meet the demand of the Lagos residents. Hence semi-formal and informal 
operations from mini buses (Danfo ), motorcycles, tricycles and boats (specially popular among Makoko Community) are being continued to fill the gap. Underlying need to fill the gap by operations have to addressed the unemployment and high poverty rate in the city and not necessarily as a choice career or grounded profession. The incursion into the transportation sector by unemployed youth and other categories of the population who seek means of livelihood has contributed to traffic chaos and unethical behaviors among the informal operators.

The road infrastructure is grossly inadequate to meet the trip demand of the residents. The road network density put at 0.6 kilometers per 1000 population is reletivey low. Lagos State has 80 cars per 1000 people with a high car density of 264 vehicles per kilometer of roadway. This is similarly efficient with a limited number of primary corridors carrying the bulk of the traffic.

\subsection{Urban transportation, traffic congestion and traffic management in Lagos mega City}

As per the findings, the growth in the number of vehicles in Lagos city continue to create countless challenges for Lagosians and the state government in particular. The state government has recently engaged in traffic management by adjusting the use of existing road system to improve traffic operations without resorting to major new constructions. Effective traffic management can improve utilization of road networks at much lower cost than constructing new and expanding existing ones. Urban traffic congestion is a condition of road networks that occurs as the usage increases and is characterized by slower speeds, longer trip times and increase vehicular queuing. (Owoputi 2015 ).

As per the findings, this situation has been occured due to the over use of the road which is as a result of the followings.

a. Too many cars on the roads due to inadequate mass transit options or other reasons.

b. Obstacles in the road causing a blockage and merger such as double parking, road work, lane closure due to utility work, road narrowing down and accidents.

c. Traffic signal out order when the computers are mal-functioning,

d. Too many pedestrian crossings due to inadequate rail freight operations.

e. Too many cars on the road due to inadequate of rail freight operations, f. Over development in areas where limited land space exist and the mass transit system is already over-crowded and the road system is inadequate,

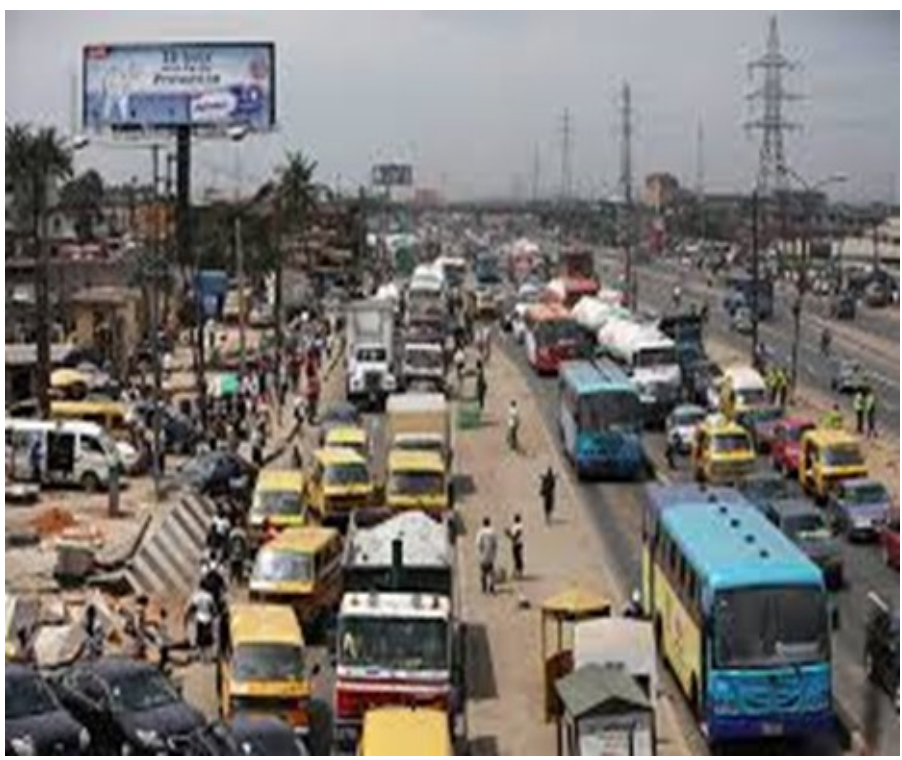

Figure 3: Source:- Photography taken at Awolowo road, ( Ikeja to Alausa) by the Author.

Recent development in managing urban transportation and land use in Lagos mega city by the State government:-

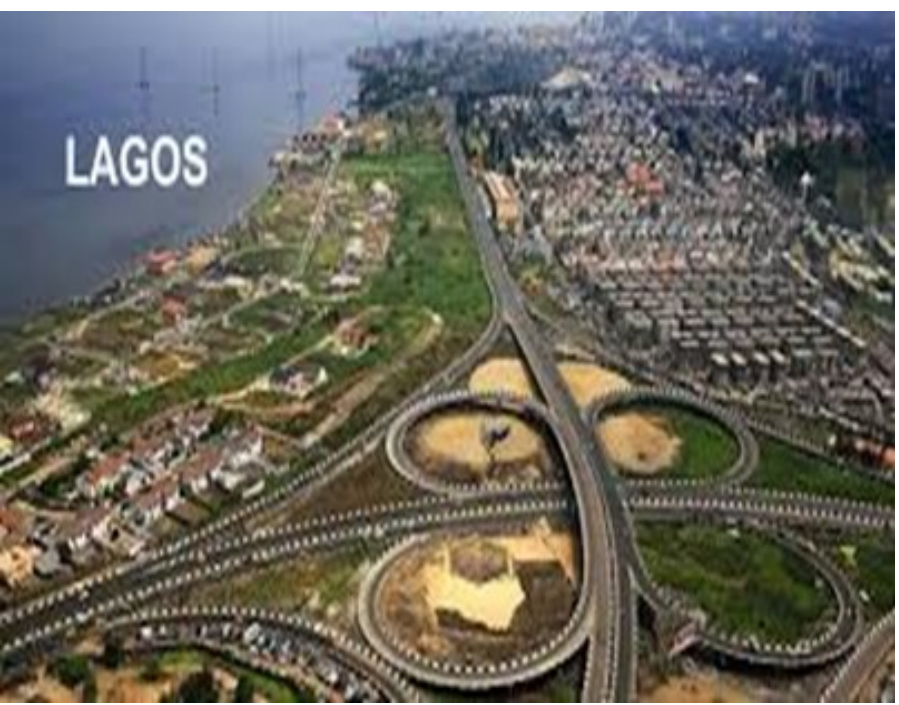

Figure 4: Source:-https:// www.google.com. Lagos, Nigeria first 8 line city road. uploads/2016/5/Lagos.

Among many other various development in managing urban mobility the following steps have already being proposed or implemented.

a. Road safety audit along Oyinkan Abayomi drive, Ikoyi

b. Rehabilitation of laybys at Mokuola, Ogba

c. SOS construction of Median Barrier from IsheriIdimu round about to Idimu Police-Station

d. Construction of Median Barrier at Alaguntan, Egbeda

e. Provision of panel mesh from ilupeju by pass to PWD, Ikeja 
f. Construction of multiple layby's at Carwash bus/ stop, Oworo

g. Provision of panel mesh from Igbobi Orthopeclic Hospital to Palmgrove bus/stop, along Ikorodu road.

h. Provision of traffic and infrastructure management at Alapere junction, Ketu

i. Construction of multiple layby's at Iyana Oworonshoki bus/stop, LAGBUS bus/stop and Alternative road, towards gridlovks resolution at Iyana Oworo, Kosofe LGA.

j. Provision of Retro-Reflective concerete Bollards from costain roundabout to Eko Bridge, Lagos

k. Re-construction of the Ifako-U-turns under the Ogudu Bridge and the Oworo road junction.

1. Construction of panel mesh along ikorodu road from Odo Iya- Alaro to Ketu interchange by BRT entrance terminal

m. Construction of corridor Approch - Lekki Axis, Ajah roundabout Ajah town.

n. Provision of clear- view fence along Ikorodu road from Ojota cloverleaf to Odo-Iyalaro

o. Provision of ultra-modern bus terminal at Tafawa Balewa Square (TBS )

p. Provision of road safety measures along Bourdillon, Alexander and Geravd Ikoyi, Lagos

q. Provision of traffic infrastructure and management at Alapere phase 11, Ketu

r. Maintenance of traffic signal light installations within Lagos mega city

s. Painting of median kerbs along specific rotes within the city

t. Painting of pavement kerbs and median Barriers within Lagos metropolis.

u. Painting of pavement kerbs along Mobolaji Bank Anthony to Lagos House

v. Painting of kerbs \& median Barrier from Ojodu - Berger through 3rd main land

\subsection{Proposed interventions and Contribution to Knowledge}

Road traffic management measures in Lagos mega city should include the followings.

a. Provision of time-based traffic lights and enforcement of traffic lights signs

b. Manning of road junctions by traffic wardens

c. Provision of off - street parking facilities where there are available spaces d. Clearing of drainages that have been stilled up

e. Rehabilitation of the existing roads and construction of new ones

f. Constructing overhead bridges and zebra crossings

g. Provision of special routes for bus rapid transit (BRT)

h. Encouragement of park and ride system

i. Educating drivers and ensure compulsory written test before the issuance of any driver's license

j. Use of mobile counts to affect immediate control

k. Regular road patrol for traffic control

1. And five basic requirements are necessary to develop and implement an urban transport strategy;- These are (a) a well defined policy (b) a national level coordinating agency between land use plan, mobility and urban city transportation (c) sufficient professional and skilled technical human resources within the coordinating and implementing agencies.

\section{Conclusion}

There is no comprehensive national urban transportation, urban mobility and urban land use planning, consequently no well- defined strategy, what exists is an amalgam of high level decisions and policies concerned with related sectors, such as roads, public transportation, urban planning, road safety and urban development with issues of mobility. The urban transportation investments that have been made in recent years are responses to crisis situation dealing with sub- sectorial problems. This weakness stems from a lack of national level agency empowered to coordinate and implement comprehensive urban transport policy measures. Consequently, its impact has been limited, it is clear from the above that the urban transportation crisis in Lagos mega city is not a short- term problems. Without some major new initiatives and a policy stance to support the private sector, the current crisis will continue beyond the first half of the 2050's. A five or more action part program me aimed at providing financial support to the private sector, commercializing the public sector facilities as well as the management of urban traffic in such a way as to help buses avoid traffic congestion, thereby enabling them to operate more speedily, reliably, comfortably and at the lowest possible costs to the nation. The urban land use plan should be coordinate with urban transportation planners and it mobility system, these will aid traffic management measures and a compressively designed and rigorously enforced could improved the general efficiency of urban transportation, urban land use plan and serve to 
make the urban environment more attractive. in the areas of non-motorized transport, alternative Rehabilitation, maintenance and public transport fuels, traffic restraint, mobility coordination, cost facility improvements is advocated. Policy analysis recovery and road safety with turn- around time and actions in the area of urban- land use plan and management are also recommended.

\section{References}

Andrew R. Goetz (2010) The Geography of Transport Systems, Second Edition. By Jean-Paul Rodriguez, Claude Comtois and Brian Slack, Economic Geography, 86:3, 321-322, DOI: 10.1111/j.1944-8287.2010.01075.x

Ayeni M. A. O. (1975) "Patterns Processes and problems of Urban Development: in Oguntoyinbo J.S. et all (eds.) a geography of Nigeria development Heinemann. pp 190-210

Badejo Dele (2014) Transporting the future today; portrait of Nigeria, 65 Inaugural lecture, Olabisi Onabanjo University Ago- Iwoye, Ogun- State.

Jayasinghe, A., Sano, K., \& Nishiuchi, H. (2015). Network Centrality Assessment (NCA) as an alternative approach to predict vehicular traffic volume: A case of Colombo, Sri Lanka. Journal of the Eastern Asia Society for Transportation Studies, 11, 834-853.

Jayasinghe, A., Sano, K., \& Rattanaporn, K. (2017). Application for developing countries: Estimating trip attraction in urban zones based on centrality. Journal of Traffic and Transportation Engineering (English Edition), 4(5), 464476.

Lagos Map: ( 2015) https:// www.google.com. Lagos, Nigeria first 8 line city road. uploads/2016/5/Lagos.

LAMATA (2015) Lagos Metropolitan Area Transport Authority Annual Conference

LURG (2009) Lagos Urban Research Group, Archive for the geography category, Where is Lagos? Geographic position. From www.lurgnetwork, World press com / category/ lagos -facts/geography.

Kadiri W.A. (1999) Effective Traffic Management in Nigeria 'A viable Safety option' Journal of transport development initiatives vol.1 pp 41-51.

Prothero, R. (1969). Urbanization in Nigeria. By Akin L. Mabogunje. London: University of London Press, 1968. Pp. 353, ill., maps. 50s. Africa, 39(4), 430-431. doi:10.2307/1157396

Owen, Alfred (1956). Strategies for Mobility. Washinton. The Brocklings Institute.

Owoputi A. E. (2015) The impact of road development and expansion on urban cities " A case study of Akure metropolis: Worldwide Journal of Multidisciplinary Research and development. Pp 46- 48.

Owoputi A. E. (2016) "Road Infrastructure and Urban Development in Akure, Nigeria: Performance Indices and Sustainable Development. Paper presented at Conference on Management and Sustainable Development FUTA 2017.

Stiffing, H.B. (2015) Urban mobility research group

Sunday \& Ajewole ( 2006 ) Urban land used and Traffic accessed from www.lagosstate gov.ng/ page links. Php.

Trim-bath S. (2011) Transportation infrastructure paving the ways STP Advisory services LLC working paper STP2011 